\title{
Information provide and learning system using augmented reality of exhibition environment
}

\author{
Jae-Young Lee*, Jun-Sik Kwon**
}

\begin{abstract}
In this study, we propose an information providing and learning system using augmented reality in the exhibition (museum, performance) environment. In a typical exhibition space, a description of a picture or a photograph is provided in a printed matter or a space in the form of an information space (explanatory space), or an auxiliary explanation using an 'audio guide' or a 'docent' program. Augmented reality technology is applied to the exhibition space in the form of a fusion of these methods, and the description of the exhibition is provided to the user in various forms such as text, picture, audio and image, thereby providing stereoscopic information and learning. We apply the augmented reality technology in a specific exhibition space and utilize it as a tool of providing information and learning using image description of pictures.
\end{abstract}

Keywords : Augmented Reality, exhibitions, Smart Learning, interaction, information

\section{전시 환경의 중강현실을 이용한 정보제공\&학습 시스템}

\author{
이재영*, 권준식**
}

요 약

본 연구에서는 전시(박물관, 공연) 환경에서 증강현실을 이용한 정보제공 및 학습 시스템을 제안한다. 일반적인 전시 공간에서는 그림이나 사진에 대한 설명을 인쇄물이나 공간에 설치(설명 공간) 형태의 정 보를 제공하거나 '오디오 가이드'나 '도슨트' 프로그램을 이용한 보조 설명이 이루어진다. 증강현실 기술 이 이러한 방식을 융합한 형태로 전시 공간에 적용되어 전시에 대한 설명이 텍스트, 이미지, 오디오 그 리고 영상의 형태로 다양하게 사용자에게 제공하여 입체적인 정보제공 및 학습을 도와준다. 우리는 특 정 전시 공간에서 증강현실 기술을 적용하여 그림에 대한 영상 설명을 이용한 정보제공 및 학습의 도구 로 활용하고자 한다.

키워드 : 증강현실, 전시, 스마트러닝, 상호작용, 정보제공

\section{Introduction}

\subsection{Augmented Reality}

* Corresponding Author : Jun-Sik Kwon Received : November 25, 2016

Revised: December 27, 2016

Accepted: Decembe 31, 2016

* MediaNArt Co. Ltd., Technical \& Management

** Semyung University, Dept. of Electrical Eng. Tel: +82-43-649-1774, Fax: +82-43-649-1774 email: jskwon@semyung.ac.kr

$\square$ This paper was supported by Semyung University Research of 2015.
Augmented reality is a technology that superimposes virtual information in real time on the real world seen by the user. It is helping to provide understanding and information about the real world and has become a subject of much interest as technology using various interfaces in future human-centered society. In addition to mobility, which is a recent advantage of mobile, augmented reality is attracting more attention as detailed information can be provided by the development of technology. Mobile augmented reality is suitable for 
ubiquitous computing environment where users can get desired information in the real world without being restricted by time and space. The augmented reality with unlimited potential is utilized in various fields such as medical, game, shopping and entertainment from the nation-based industry. In particular, the education and cultural industries and augmented reality can produce a good synergy. (Figure 1) shows the definition of augmented reality using the definitions of Azuma and Milgram[1][2].

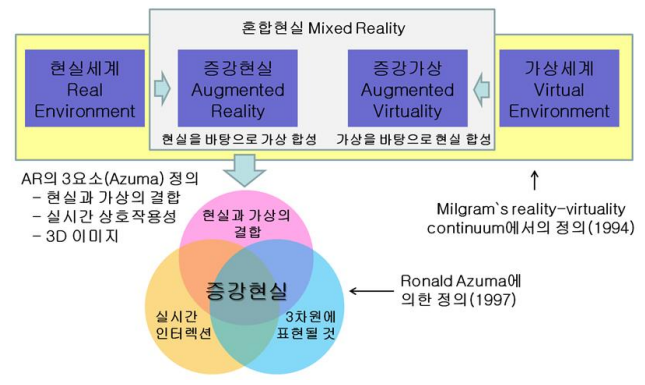

(Figure 1) Relationship between the real world and virtual world

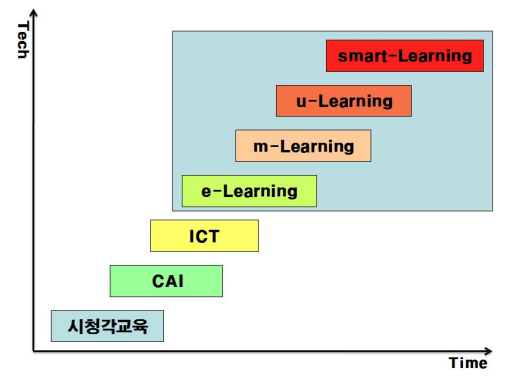

(Figure 2) Trend changes in the education system

\subsection{Information Delivery \& Learning}

Various methods have been developed and developed to help users learn. (Figure 2) shows the trend of educational system from audiovisual education to current smart learning from the trend of e-learning market of $\mathrm{R} \mathrm{\&} \mathrm{D}$ Biz[3].

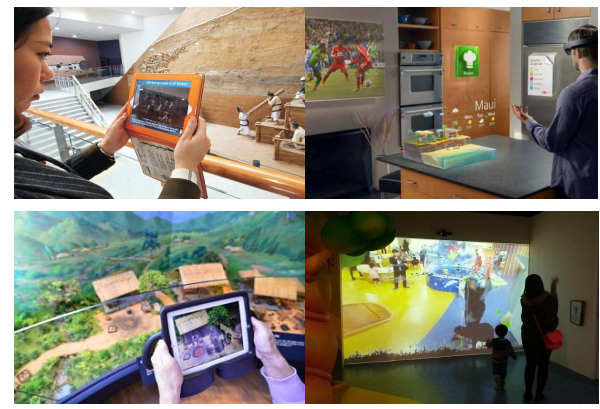

(Figure 3) Using Augmented Reality Technology in Exhibition Space

The attempt to change the new educational method started with the audiovisual education in the 1980 's, which is an auxiliary learning role using video and sound. In the 1990s and 2000s, the trend of education system changed with the use of ICT(Information \& Communication Technology) and CAI (Computer Assisted Instruction) which helped to learn by using computers. As the age of e-learning began, it began to change rapidly. E-Learning means learning activities that are carried out using "electronic medium" based on information and communication technology and network infrastructure. In other words, all the processes of learning and teaching are composed of electronic systems. M-Learning means learning using mobile devices with good portability. U-learning means using a ubiquitous environment, which means that learners can freely access and learn from the network regardless of the location of the network or computer[4][5]. The word smart learning is a new emerging word. This means that smart devices that have higher performance than mobile devices are used for e-learning using mobile devices in the ubiquitous environment[6].

\subsection{Exhibition Environment}

In the exhibition space, the augmented reality technology is gradually becoming a new technology. The convergence of new 
technologies and arts is becoming increasingly common as the use of smart phones and existing monolithic exhibits are eliminated. There is also a way to show virtual performers by fusion with hologram technology, or to transmit information by exposing additional information of performances. The museum provides an overview of various artifacts and exhibits, as well as the overall learning of moving and closure of museum spaces. In this paper, we apply smart learning based information delivery system based on existing augmented reality to exhibition \& performance space. First, we describe the existing augmented reality learning system implemented by computer, and discuss the application of the augmented reality learning system to exhibition space and its development direction.

\section{Proposed method}

\subsection{Augmented Reality System}

The proposed smart learning system utilizes the advantages of existing e - learning system and image - based augmented reality. It is possible to enhance the learning effect by inducing the concentration and interest of the user by expressing the part where the user is difficult to directly observe or difficult to express the book through the 3D virtual object. In order to realize augmented reality in mobile devices, we use the camera installed in mobile device to find the feature of the object and acquire the desired position coordinates to synthesize the object [7].

There are a lot of AR systems that can enhance natural objects by extracting natural feature points from the real world and tracking them. The advantage of markerless based AR systems is that they can be configured in a more natural way because the user's accessibility is easier because they do not use specific predefined marker types. We use SURF(Speeded Up Robust Features) algorithm in natural feature point detection light tracking algorithms[8].

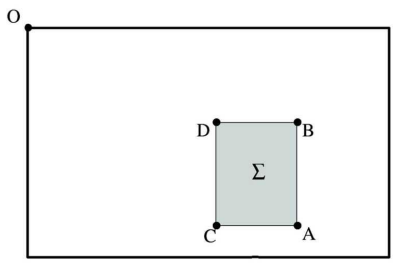

(Figure 4) Integral image computation method

The process of SURF algorithm can be classified into cumulative image generation, scale space configuration, localization, main direction allocation, and descriptor extraction. Cumulative image generation is a part used in the following process by the process of Equation (1). We can obtain the sum of squares by summing the cumulative values of the overlapping $\mathrm{D}$ after finding the image difference of the points $\mathrm{B}$ and $\mathrm{C}$ to the cumulative image value of the A point in the rectangular area of the (figure 4). In this method, regardless of the size of the area, the sum of the specified rectangular areas is obtained by using the three arithmetic operations as shown in equation (2).

$$
\begin{aligned}
& I_{\Sigma}(X)=\sum_{i=0}^{i \leq} \sum_{j=0}^{i \leq y} I(i, j) \\
& \Sigma=A-B-C+D
\end{aligned}
$$

(Figure. 5) the image pyramid shape is formed in the scale space configuration. In this method, the size of the filter is adjusted so as to have an effect on the scale change, and the filter is adjusted without changing the size of the image, so that the aliasing does not appear. The localization process compares the candidate points found in the previous process with the surrounding values. The portion having the largest value is determined 
as a similarity point and extracted as a minutiae point.

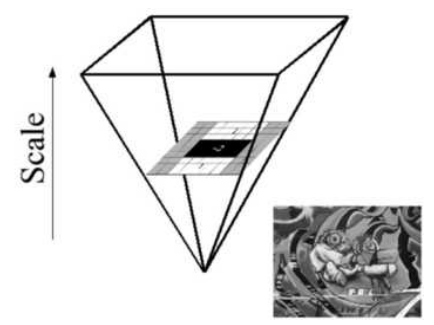

(Figure 5) Convolution way to find the features: change the size of the rectangular filter

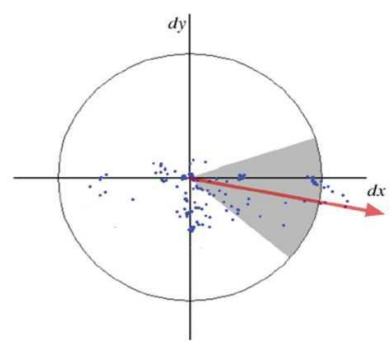

(Figure 6) Orientation allocation

To find the main direction of the feature point, we calculate the haar wavelet response for the $\mathrm{x}$ and $\mathrm{y}$ directions of the feature point candidates in the 6s (scale) circle around the feature point candidate. In (Figure 6), the blue dots in the circle are the values of the response values. The red arrows represent the sum of the responses in the fan-shaped region of about 60 degrees and are represented as vectors. A vector is generated by calculating the sum of $\mathrm{x}, \mathrm{y}$, and $\mathrm{y}$, response while sliding a window of 60 degrees, and the vector with the longest vector length is assigned as the orientation. After performing the orientation, divide the descriptor window again by $4 \times 4$. At this time, each divided area calculates the spare feature points distributed in the size of $5 \times 5$ with the haar wavelet.

\subsection{Installation type system}

It is an installation type system that constitutes a space in the exhibition space, and it has a space structure in which a user enters a specific space. This space is composed of various spaces such as a space for projecting images and a space for viewing while staying. (Figure 7) shows a photo (image) type marker for the user to experience augmented reality in the above exhibition space. It is installed in the form of exhibition in a specific space where images in the form of frames suitable for the exhibition space are arranged.

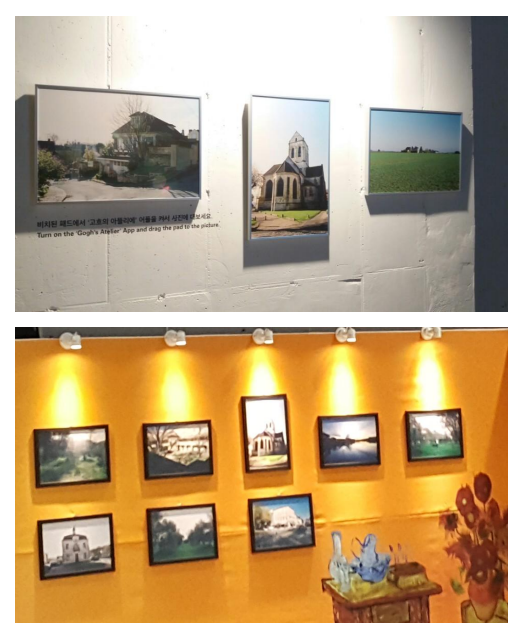

(Figure 7) Photo installation of exhibition space

\subsection{Moving type system}

It is a system where users use smart devices (smart phones, tablets, etc.) in the exhibition space. The user can use the camera of the smart device and use it throughout the exhibition without restriction of time and space. It can act as an intermediary (image, graphic, etc.) of information transfer in all space related to exhibition and can be updated in real time. In other words, when visitors take a photo of the visitor, they can use it as a form to be displayed in a specific exhibition 
space.

(Figure 8), it is installed using a specific type of markers or objects around the picture frame or picture in the exhibition space. The augmented reality can be used to acquire additional information related to the pictures displayed by the spectators using the smart equipment. This information is structured so that it can be learned in various forms such as a description of a text form, a description of a picture form, a description of a video form, and a description of a sound form[9][10].
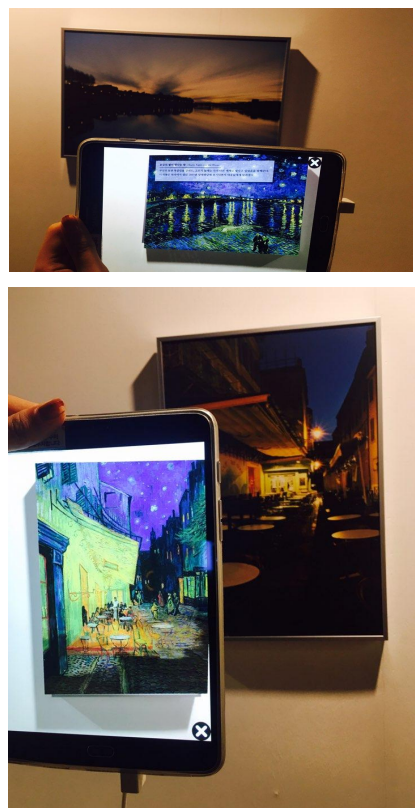

(Figure 8) Augmented Reality portable of exhibition space
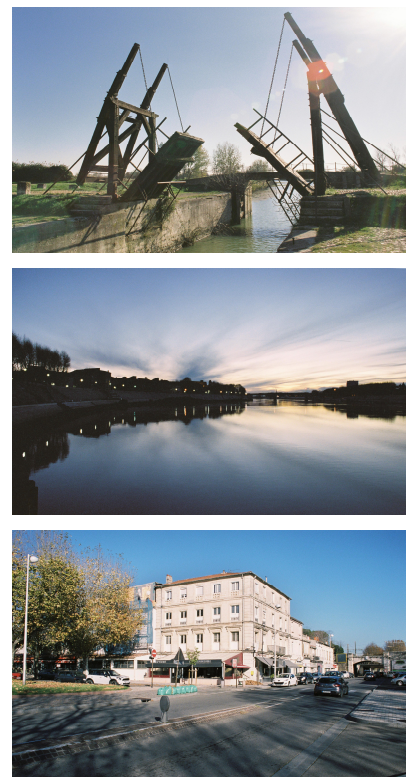

(Figure 9) Photo Target source(Van Gogh)

\section{Experimental and Evaluation}

The experiment was tested on an Android-based smart pad (Galaxy Note 10.1 and Galaxy Note 8) to test the mobile environment. A method of realizing augmented reality in an Android-based smart device is a method of finding a feature point using a camera input image and synthesizing a virtual object using a position and a direction in a three-dimensional space. With Qualcomm's Vuforia, we have a strength to use with various development environments conveniently. In the proposed method, augmented reality information transfer tool of the exhibition space is realized by synthesizing virtual text and 3D object in real time by recognizing image marker in the development environment [11].

The sources used in the experiments were Vincent Van Gogh's paintings, popularly known to the public. The area of Auvers-Sur-Oise where the scenery of the 
city is preserved is still preserved and many of the scenery and buildings that are seen by Van Gogh are still preserved. It was tested using the scenery photographs here as a target source. (Figure 9), the target source was tested based on three of the following: Cafe Terrace at Night, The Draw Bridge, and Starry Night Over the Rhone .

\subsection{Production of video content}

The augmented reality contents to be used in the exhibition space are intended to convey various information about pictures. Additional text-based information transfer to pictures, information on drawing age and living environment using 2D-based photographs, 2D reconstruction of hard-to-communicate parts, 3D information transmission, sound And a method of transmitting the audio guide as a reinforcement of the start transmission.

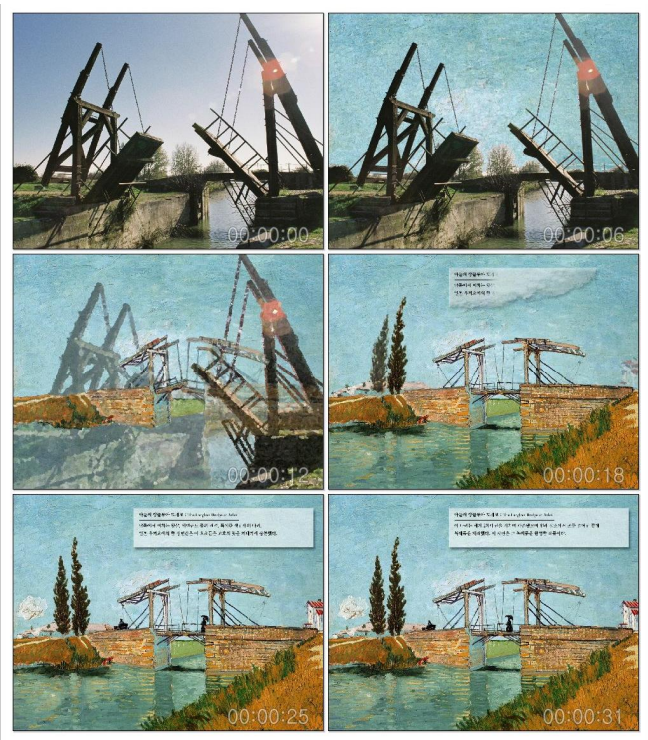

(Figure 10) Test the video source 1

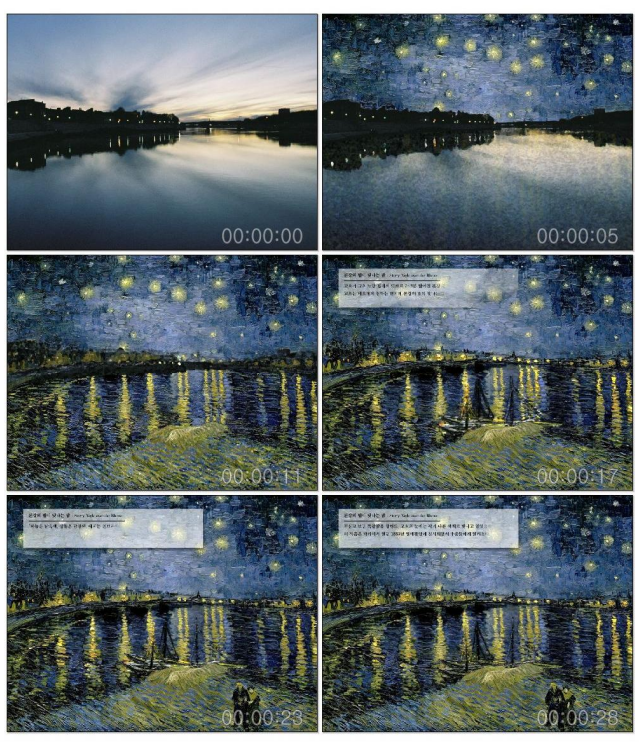

(Figure 11) Test the video source 2

We have conducted tests on the visual delivery method in duplicate. (Figure 9) is a still image of the video content whose target source is changed to a picture and explained. (Figure 10), (Figure 11) and (Figure 12), it is expressed as a still shot of the image using a video player. These pictures have been tested for content in which the picture changes to a picture and a textual description of the picture appears. In the above image, the augmented reality technology is used on the image target to show how the building or landscape gradually changes to the picture, so that it is tested and made to increase the understanding of the place where the exhibition visitors are made. In addition, knowledge can be conveyed along with comprehension through name, year of production, and explanation of simple works. 


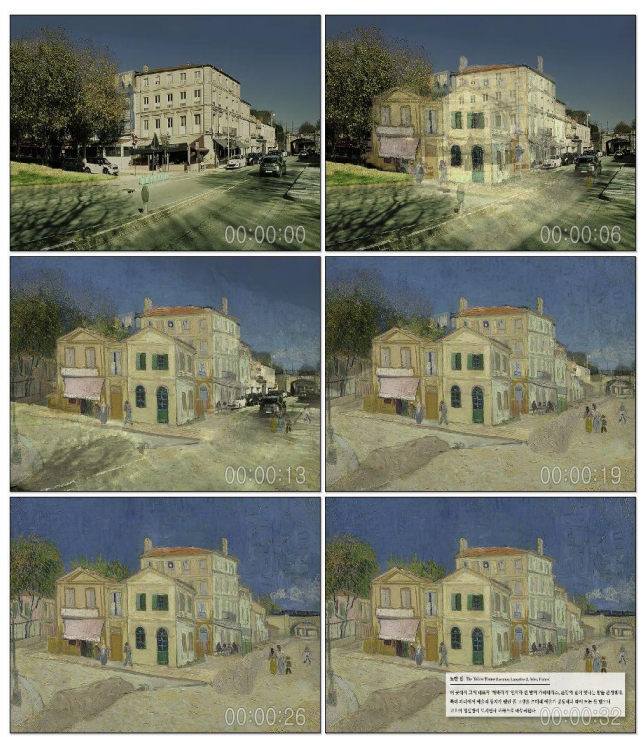

(Figure 12) Test the video source 3
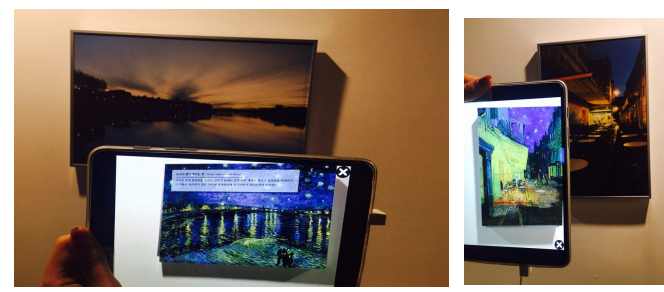

(Figure 13) Movement-based augmented reality test

\subsection{Application of Augmented Reality in Exhibition Space}

In the exhibition space, the augmented reality can be realized by integrating with the exhibition space by using specific markers, texts and images according to the way of designing the space opportunity. We constructed the space and composed the environment by using the photographs in duplicate, so that the user could recognize and use the pads to feel and experience it. (Figure 13), you will learn how to change the picture to a picture, and you will also see a description of the text. Through this, it can be used not only as an exhibition but also as a medium of knowledge transfer.
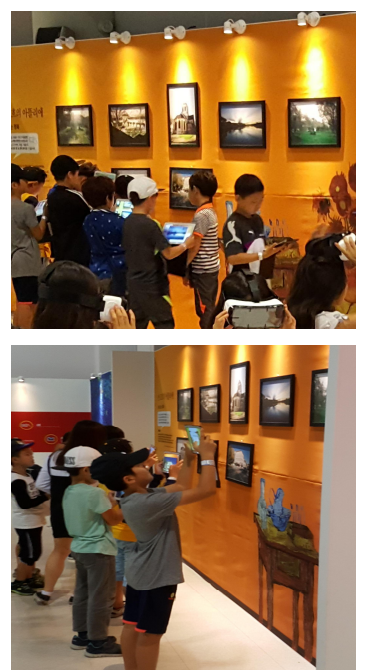

(Figure 14) Test the installation of the exhibition space

As shown in (Figure 14), the augmented reality method using the exhibition space is a method in which each interior of the exhibition space is created and provided as an 'image target' for the user. Inside the exhibition space, users will be able to feel the fun of finding a virtual treasure, and not only the contents of the exhibition, but also the space and the interior will be interesting.

Through experiment, we tried to provide various information by using augmented reality technology in exhibition space. A mobile augmented reality system was created and applied to contents suitable for exhibition. Experiments were carried out by focusing on the application of technology to the user and the application in the exhibition space. Ease of installation and ease of use are also considered to be no problem.

\section{Conclusion and Future Research}


With the development of various augmented reality technologies, studies are being actively pursued in various environments. In the general PC-based research, the development of various types of smart devices and the development of various types of HMD have led to the spread of popular devices. In a specific environment of exhibition and performance, this method can be applied in various ways. Especially, smart devices are becoming popular among users. In this environment, the convergence of smart learning techniques and the use of various information in real time as augmented reality technology are helpful for learning. Based on this research, we plan to further develop the mobile application of augmented reality and application of exhibition and performance using various contents. In addition, since various sensing technologies are developed and applied between user and system, fusion technology is also being studied and developed. There will be a lot of advancement in the technology applied to all the spaces in which we live and work and the interaction between people and computers.

Research on the application of Augmented Reality technology to exhibition space is continuing through continuous development of technology and application of contents. In addition, we are also expanding the user experience into realistic video contents through the combination of various technologies. If augmented reality is combined with various technologies, it will be possible to transmit information through advanced digital display.

\section{References}

[1] R.Azuma, Y.Baillot, R.Behringer, S.Feiner, S.Julier, B.MacIntyre, "Recent advances in augmented realit y," IEEE Computer Graphics and Applications, Vol. 21, No. 6, pp.34-47, Nov/Dec 2001.
[2] P.Milgram. H.Takemura. A.Utsumi. F.Kishino, "Aug mented reality: a class of displays on the reality-virt uality continuum", Telemanipulator and Telepresen ce Technologies, 282, December 1995.

[3] R\&DBIZ, "e-Learning Market Trends", pp. 1-13, 2007

[4] J. L. Moorea, C. Dickson-Deaneb, K. Galyenb, "e-Le arning, online learning, and distance learning enviro nments: Are they the same?", The Internet and Hig her Education, Vol.14, No.2, pp.129 - 135, March 201 1.

[5] B. S. Song and S. G. Kwon, "oncept of e-Learning Educational Innovation and Trends", IITA Week Te chnology Trends Vol. 1305, 2007.

[6] A. Syvanen, R. Beale, M. Sharples, M. Ahonen, P. Lonsdale, "Supporting pervasive learning environm ents: adaptability and context awareness in mobile learning”, The Journal of Korean association of com puter education, Vol. 14, No.2, Mar. 2011.

[7] D.Wagner, G.Reitmayr, A.Mulloni, T.Drummond, D. Schmalstieg, "Real-time detection and tracking for augmented reality on mobile phones ", IEEE Transa ctions on Visualization and Computer Graphics, Vol. 16, No.3, pp.355-368, 2009.

[8] H. Bay, T. Tuytelaars, and L. V. Gool, "SURF: Sp eeded Up Robust Features" European conference on computer vision, pp. 404-417, 2006.

[9] Jae-Young Lee and Jun-Sik Kwon, "Touch-based Gaming System using Augmented Reality Technolo gy", Journal of Digital Contents Society, vol. 15, No 1, pp.69-76, 2014

[10] Ju-Yong Lee and Jun-Sik Kwon, "Error Correction Scheme in Location-based AR System Using Smart phone", Journal of Digital Contents Society, vol. 15, No 2, pp.179-187, 2015

[11] Vuforia Augmented Reality SDK https://developer.vuforia.com/ 


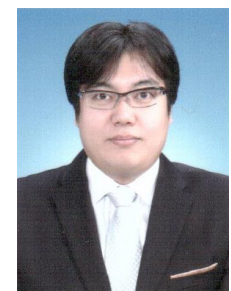

\section{이 재 영}

2007년: 중앙대학교 첨단영상대학 원(공학석사)

2013년: 중앙대학교 첨단영상대학 원(공학박사)

2007년 2014년: 세명대학교 전기공학과 강사

2013년 2013년: 강남대학교 컴퓨터미디어정보공학 부 강사

2010년 2015년: 남서울대학교 멀티미디어학과 강사 2014년 현재: (주)미디어앤아트 기술운영팀장

관심분야: 영상처리, 증강현실, 상호작용, 모션그래픽, $3 \mathrm{D}$ 맵핑, 미디어파사드 등

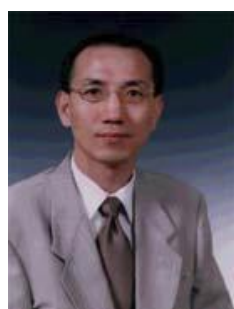

\section{권 준 식}

1986년 중앙대학교 전자공학과 졸 업(공학석사)

1995년 중앙대학교 전자공학과 졸 업(공학박사)

1986년 1987년: 현 대전자

1987년 1991년: 금성통신

1995년 현 재: 세명대학교 전기공학과 교수 관심분야: 영상신호처리, 컴퓨터비전, 수리형태학, 영 상정보은닉 등 